\title{
Techno-economic Analysis of Solar Photovoltaic Power Plant for Hotel in Maharashtra
}

\author{
Sunil D. Bagade ${ }^{1}$, Mahesh N. Shelar ${ }^{2}$ \\ Assistant Professor, Mechanical Department, Dr. Daulatrao Aher College of Engineering, Karad, India ${ }^{1}$ \\ Associate Professor, Mechanical Dept, K. K. Wagh Institute of Engineering Education and Research, Nashik, India ${ }^{2}$
}

\begin{abstract}
In this paper, the potential and the cost-effectiveness of a solar photovoltaic power plant for meeting the energy demand of Hotel in Nashik (India) is analyzed. Also, the energy demand of Hotel for year 2016 was been estimated $(68 \mathrm{KW})$ and the design of the solar PV power plant of $20 \mathrm{KW}$ capacity was proposed and installed Simple payback period is 2.41 years which is quite attractive.
\end{abstract}

Keywords: Photovoltaic, Solar power plant, Techno-economic analysis, Payback period.

\section{INTRODUCTION}

Solar photovoltaic power system is the most promising non conventional energy technology. photovoltaic systems range from small, rooftop-mounted or building-integrated systems with capacities from a few to several tens of kilowatts, to large utility-scale power stations of hundreds of megawatts. Nowadays, most photovoltaic systems are grid-connected, while off-grid or stand-alone systems only account for a small portion of the market.

The diagram below shows the basic building blocks of a small stand-alone off-grid photovoltaic power generating system. A grid connected system would not need the battery. They do however need alternative capacity to come on stream to carry the load during the hours of darkness.

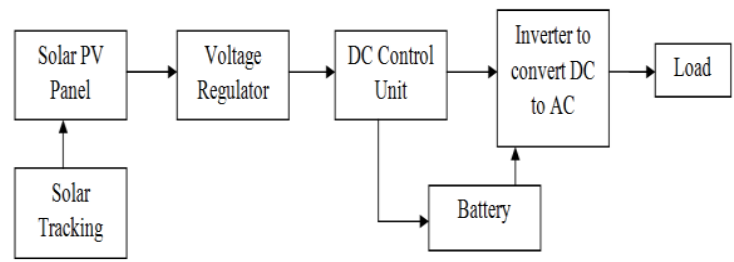

Fig. 1 Photovoltaic Electrical Power Generation

\section{Design of Solar PV Plant}

A solar photovoltaic system was installed at Hotel Prestige Pride, Nashik in Maharashtra State. The load study conducted for Hotel is given in Table I. The consumer is a commercial consumer with an average monthly bill of Rs 68,000 per month .The higher tariff of Rs 12 per $\mathrm{kWh}$ was because of the differential tariff system levied by MSEDCL. This tariff system provides incentive to consumers to reduce higher energy consumption. To shave off the higher energy consumption the solar PV of $20 \mathrm{~kW}$ capacity was designed. The technical specifications of the photovoltaic system installed are included in Table II.

\section{III.TECHNO-ECONOMICS}

Component wise cost of PV system was considered for calculating the capital cost. This is included in Table III. The annual energy output after installation of PV system was monitored for four months and the energy bill for the period was noted. Table IV summarizes the average monthly savings.

TABLE I CONNECTED LOAD OF HOTEL

\begin{tabular}{|c|l|l|}
\hline $\begin{array}{c}\text { Sr. } \\
\text { No. }\end{array}$ & \multicolumn{1}{|c|}{$\begin{array}{c}\text { Connected } \\
\text { Load }\end{array}$} & \multicolumn{1}{|c|}{$\begin{array}{c}\text { Power Consumption } \\
(\text { Kw) }\end{array}$} \\
\hline 1. & Lighting & 18 \\
\hline 2. & Lift & 3.7 \\
\hline 3. & Air Conditioning & 33 \\
\hline
\end{tabular}

TABLE II TECHNICAL SPECIFICATIONS

\begin{tabular}{|c|l|l|}
\hline 1. & Present Connected Load & $55 \mathrm{Kw}$ \\
\hline 2. & Installed PV System & $20 \mathrm{Kw}$ \\
\hline 3. & No. of Panels & 64 \\
\hline 4. & $\begin{array}{l}\text { Peak Power Capacity per } \\
\text { panel }\end{array}$ & $315 \mathrm{Watt}$ \\
\hline 5. & Total Capacity & $64 * 315=20160 \mathrm{~W}$ \\
\hline
\end{tabular}

TABLE III BREAK UP OF CAPITAL COST

\begin{tabular}{|l|l|l|}
\hline Sr. No. & \multicolumn{1}{|c|}{ Component } & \multicolumn{1}{|c|}{ Cost $($ Rs. $)$} \\
\hline 1. & Solar PV Panel & 740000 \\
\hline 2. & Switch gear (4 pole) & 18000 \\
\hline 3. & Inverter & 240000 \\
\hline 4. & L \& T Netmeter & 22000 \\
\hline 5. & Structure of GI & $75($ per $\mathrm{kg})$ \\
\hline & Total Cost & 1450000 \\
\hline
\end{tabular}

Cost $/ \mathbf{k W}=1450000 / 20$ $=72500 \mathrm{Rs} . / \mathrm{kW}$ 
International Advanced Research Journal in Science, Engineering and Technology

National Conference on Design, Manufacturing, Energy \& Thermal Engineering (NCDMETE-2017)

AGTI's Dr. Daulatrao Aher College Engineering, Vidyanagar Extension, Karad

Vol. 4, Special Issue 1, January 2017

TABLE IV MONTHLY SAVINGS AFTER PV

INSTALLATION

\begin{tabular}{|l|l|l|}
\hline $\begin{array}{l}\text { Sr. } \\
\text { No. }\end{array}$ & \multicolumn{1}{|c|}{ Parameter } & \multicolumn{1}{c|}{$\begin{array}{c}\text { Amount } \\
\text { (Rs./ month) }\end{array}$} \\
\hline 1. & Electricity Bill before Pv & 68000 \\
\hline 2. & Electricity bill after PV & 18000 \\
\hline & Net Savings & $68000-18000=$ \\
& & 50000 \\
\hline
\end{tabular}

Annual Savings $=50000 \times 12$

Simple Payback Period =

$1450000 / 600000=2.41$ years

\section{IV.CONCLUSION}

Study has been carried out to assess the technical feasibility and economic viability of Solar PV plant. The feasibility of solar PV system can be attributed to differential tariff and saving in battery cost with net metering. Installation of solar PV systems with net metering are therefore recommended.

\section{REFERENCES}

[1] Besarati SM, Padilla RV, Goswami DY, Stefanakos E. The potential of harnessing solar radiation in Iran: generating solar maps and viability study of PVpower plants. Renew Energy 2013;53:1939

[2] Khelif A, Talha A, Belhamel M, Arab AH. Feasibility study of hybrid Diesel-PV power plants in the southern of Algeria: case study on AFRA power plant.

[3] Radhi H. On the value of decentralized PV systems for the GCC residential sector. Energy Policy 2011;39:20207

[4] Pavlovic T, Milosavljevic D, Radonjic I, Pantic L, Radivojevic A, Pavlovic M. Possibility of electricity generation using PV solar plants in Serbia.Renew Sustain Energy Rev 2013;20:201

[5] Muneer T, Asif M, Munawwar S. Sustainable production of solar electricity with particular reference to the Indian economy. Renew Sustain Energy Rev 2005;9:444

[6] Mekhilef S, Saidur R, Safari A. A review on solar energy use in industries. Renew Sustain Energy Rev 2011;15:1777

[7] Sunil Bagade, Nagesh Patil, Govind Kulkarani, Hybrid Solar Power Plant: Assessment of Its Economic Viability In Indian Context, COEP, Pune, Maharashtra, India, 2013. 